Arab Univ. J. Agric. Sci., Ain Shams Univ., Cairo, Egypt

29(1), 293 - 305, 2021

Website: http://ajs.journals.ekb.eg

DOI: 10.21608/ajs.2021.59713.1337

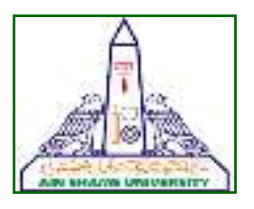

293

\title{
Combining Ability for Grain Yield and Some Agronomic Traits in Diallel Crosses of Bread Wheat under Nitrogen Stressed Conditions
}

\author{
Yassmin TM Emam*, Kamal IM Ibrahim, Ahmed A Mohamed, \\ Yasser A El-Gabry \\ Agronomy Dept, Fac of Agric, Ain Shams Univ, P.O. Box 68-Hadayek Shoubra 11241, \\ Cairo, Egypt \\ *Corresponding author: YassminTarek@agr.asu.edu.eg
}

Received 8 February, 2021

Accepted 10 March, 2021

\begin{abstract}
Six bread wheat genotypes and their $15 \mathrm{~F}_{1}$ crosses were evaluated under two nitrogen fertilization levels (40 and $80 \mathrm{~kg} \mathrm{~N} / \mathrm{fed}$ ) to estimate combining ability for days to heading, plant height, spike length, number of spikes/plant, kernels number/spike, weight of 100-kernels and grain yield/plant during 2018/19 season. Results revealed that significant nitrogen levels $(\mathrm{N})$ mean squares were detected for all studied characters. Mean squares due to genotypes $(\mathrm{G})$, parents and crosses for the studied characters were significant at both nitrogen levels and their combined analyses. Also, G x N interaction was highly significant for the studied characters. The general and specific combining ability variances were found to be significant for all studied characters at both-N-levels and their combined analyses. GCA/SCA ratios were less than unity for all studied characters at both $\mathrm{N}$-levels and their combined data. The behavior of gene action varied from nitrogen level to another where the interactions of GCA and SCA with nitrogen levels were significant for most studied characters. Sakha 93 was identified as the most useful source for increasing favorable alleles for grain yield/plant, kernels number/spike and weight of 100-kernels under N-stress conditions, while Giza 168 was the best combiner
\end{abstract}

for earliness at the two $\mathrm{N}$ levels. Cross combinations; Sakha 93 x Sids 12 and Sakha 93 x Misr 1 gave the best SCA effects for grain yield/plant under N-stress conditions. Significant positive correlations were detected between means of parents and $F_{1}$ crosses with their GCA and SCA effects for most studied characters under the two nitrogen levels, respectively.

Keywords: Bread wheat; Combining ability; Gene action; Nitrogen stress

\section{Introduction}

Bread wheat is one of the most important crops in Egypt. The local production covers less than half of the local consumption. Increasing wheat productivity is a nation target in Egypt to reduce the gap between wheat production and consumption. The production of wheat can be increased by increasing the agricultural area or by increasing yield productivity per unit area. Currently, it is difficult to increase the agricultural area of wheat due to competition with other winter crops as well as restricted reclaimed lands and water shortage. Therefore, the alternative strategic solution is use high yielding cultivars characterized by tolerance against environmental stresses, especially soil nitrogen deficit, which affect the 
production of wheat. Applying nitrogen fertilization is the most important cultural practices to maximize wheat productivity through improving vegetative growth and enhancing kernel set. The needs of new wheat genotypes to high doses of nitrogen fertilizer became important to express full yield potential. To decrease the cultivation costs the breeders should develop new wheat genotypes with high tolerance to nitrogen deficiency to avoid the effect of nitrogen to the land and atmosphere pollution and other components of the ecosystem (Bouwman et al 2002). Nowadays, many efforts are done through genetic improvement to maximize the productivity of wheat. To establish an effective breeding program, enough information about the components of genetic variance and their interactions with nitrogen applications must know by the breeder. Diallel analysis is an attempt to divide the total variation into genetic and environmental variations and to subdivide genetic variation into its additive and non-additive genetic components. These estimates can then be used to draw conclusions about the genetic systems controlling grain yield and the other important characters as well as the best breeding strategy to be used to improve them. Several researchers found that the additive gene action was important in the inheritance of grain yield (Motawea 2017), plant height (Nathan and Moubarak 2016) and number of spikes/plant (Kamaluddin et al 2007). On the other hand, other investigators mentioned that the non-additive genetic effects played the important role in the inheritance of grain yield (Farooq et al 2019; El-Said 2018; Ayoob 2020) and spike length (El-Hosary et al 2012; Kutlu and Sirel 2019).

Therefore, the present study aimed to estimate general and specific combining abilities and their interactions with different nitrogen fertilization levels for seven studied characters and to determine the promising parents and crosses under low and recommended nitrogen treatments in a six parental half diallel set of wheat crosses.

\section{Materials and Methods}

Six bread wheat genotypes namely; Giza 168, Sakha 93, Sids 12, Misr 1, Cham 4 and Line 36 were chosen on the basis of their diversity in some agronomic characters and nitrogen stress tolerance to achieve this investigation (Table 1). Seeds of the four local cultivars; Giza 168, Sakha 93, Sids 12 and Misr 1 were provided from Wheat Res. Dept., Field Crops Res. Inst., ARC, Giza, Egypt. Whereas, the cultivar Cham 4 was introduced from Syria and the promising Line 36 was developed by (El-Marakby et al 1994) through the breeding program at the Agronomy Dept., Fac. of Agric., Ain Shams Univ., Egypt. This study was conducted during three successive growing seasons of 2016/17, 2017/18 and 2018/19. In 2016/17 growing season, a half diallel set of crosses among the six parents was done at the experimental farm of the Fac. of Agric., Ain Shams Univ., at Shoubra El-Kheima, Kalubia Governorate, Egypt, to obtain the seeds of $F_{1}$ crosses. In 2017/18 season, the half diallel cross set was again done to increase quantity of $F_{1}$ seeds. In 2018/19 season, seeds of parents and their $15 \mathrm{~F}_{1}$ crosses were sown on $1^{\text {st }}$ December 2018 in the Agric. Res. Stat., Fac. of Agric., Ain Shams Univ., at Shalakan, Kalubia Governorate, in two separate and adjacent field experiments representing two different nitrogen fertilization levels; $80 \mathrm{~kg} \mathrm{~N} / \mathrm{fed}$ (recommended level) and $40 \mathrm{~kg} \mathrm{~N} / \mathrm{fed}$ (low level). Each experiment was included the $15 \mathrm{~F}_{1}$ 's and their respective parents (21 entries) and designed in a complete randomized block with three replications. The preceding summer crop was sweet corn. Each experimental plot consisted of two rows for each genotype. Row was $2 \mathrm{~m}$ in length and $30 \mathrm{~cm}$ width, seeds were spaced at $10 \mathrm{~cm}$ within rows and one plant was left per hill. Nitrogen fertilizer was added in the form of Urea $(46.5 \% \mathrm{~N})$. The amount of each dose was divided into two parts; the first part (1/3) was immediately applied before the first irrigation, while the second one (2/3) was 


\section{Combining Ability for Grain Yield and Some Agronomic Traits in Diallel Crosses of Bread Wheat under Nitrogen Stressed Conditions}

Table 1. Name, pedigree and origin of six wheat genotypes used in the present study

\begin{tabular}{|c|c|c|}
\hline Name & Pedigree & Origin \\
\hline Cham 4 & Flk's'-Hork CM39816-1S-1AP-0AP & Syria \\
\hline Giza 168 & MRL/Buc//Seri CM93046-8M-0Y-0M-2Y-0B & Egypt \\
\hline Line 36 & Giza155XMD689IB/Chere"S"Tolba94. & Egypt \\
\hline Sakha 93 & S92/TR 810328 S 8871-1S-2S-1S-0S & Egypt \\
\hline Sids 12 & Buc//7C/ALD/5/MAYA74/ON//1160.1473// & Egypt \\
& $\begin{array}{c}\text { BB/GLL/4/CHAT"S"/6/MAYAVUL//CMH74A. } \\
\text { 6304/*SX SD70964-SD-1SD-1SD-0SD }\end{array}$ & Egypt \\
\hline Misr 1 & $\begin{array}{r}\text { OASIS/SKAUZ//4*BCN/3/2* } \\
\text { PASTORCMSSOOYO1881T050 } \\
\text { M30Y030M030WGY33MS }\end{array}$ \\
\hline
\end{tabular}

applied before the second irrigation. Other cultural practices were followed as usually recommended for the ordinary wheat fields in the region of the experiment. Data were taken randomly on 10 individual guarded plants for the following characters; days to heading, plant height $(\mathrm{cm})$, spike length $(\mathrm{cm})$, number of spikes/plant, kernels number/spike, weight of 100-kernels (g) and grain yield/plant (g).

The ordinary analysis of variance for single and combined data was firstly performed to test the significance of observed differences between genotypes for each studied trait on the mean plant basis according to (Gomez and Gomez 1984). The combined analyses were based on the homogeneity of error test. The analysis of variance for combining ability was estimated using (Griffing's 1956) method 2 and model 1. Rank correlation coefficients were estimated between performance of parents and their GCA effects and between performance of $F_{1}$ crosses and their SCA effects under each nitrogen level.

\section{Results and Discussion}

\subsection{Analysis of variance}

Mean squares for grain yield and some agronomic characters of the 21 wheat genotypes at each nitrogen fertilization level and combined analyses are illustrated in (Table 2). The results showed that mean squares due to nitrogen fertilization levels for all characters were significant, suggesting that these characters are influenced by different nitrogen fertilization levels. Moreover, significant differences were detected between each of genotypes, parents and crosses for all studied characters at both nitrogen levels and combined analyses, indicating sufficient variability existed in these genotypes, which could be exploited in wheat breeding programs for improving grain yield and its related characters especially under nitrogen stressed conditions. These findings are in agreement with those obtained by (Al-Naggar et al 2015a; Saleh and Mohamed 2016; AlNaggar et al 2017a), who found significant genotypes and nitrogen fertilization treatments mean squares for grain yield and one or more of its components in wheat. In addition, interactions of genotypes with nitrogen treatments were significant for the studied characters, reflecting that the performance of genotypes were inconsistent in their responses to nitrogen treatments. Such result indicated the importance of testing these genotypes under several environments for better evaluation of genotypic performance. Similar findings were mentioned by (Saleh and Mohamed 2016; Mosanaei et al 2017). 


\begin{tabular}{|c|c|c|c|c|c|c|c|c|c|c|c|c|c|c|c|c|c|c|c|c|}
\hline & u & 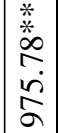 & $\stackrel{?}{\circ}$ & $\begin{array}{l}\frac{*}{*} \\
\stackrel{m}{\sigma} \\
\dot{0}\end{array}$ & 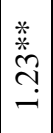 & 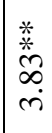 & 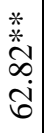 & $\mid$\begin{tabular}{l}
$*$ \\
\multirow{*}{*}{} \\
$\tilde{*}$ \\
$\stackrel{+}{+}$
\end{tabular} & 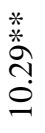 & $\mid \begin{array}{l}\stackrel{*}{*} \\
\stackrel{\sim}{i} \\
i\end{array}$ & 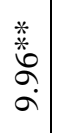 & $\begin{array}{l}\dot{0} \\
\dot{0}\end{array}$ & $\mid \begin{array}{l}\stackrel{*}{*} \\
\stackrel{*}{*} \\
\stackrel{0}{0}\end{array}$ & 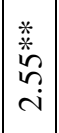 & $\mid$\begin{tabular}{l}
$*$ \\
\multirow{*}{*}{} \\
0 \\
0 \\
$i$
\end{tabular} & 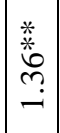 & $\begin{array}{l}\tilde{b} \\
\dot{0}\end{array}$ & $\frac{\vartheta}{0}$ & $\mid \begin{array}{l}\mathbb{C} \\
\dot{+}\end{array}$ & $\hat{2}$ \\
\hline & $\tilde{z}$ & & $\begin{array}{l}\stackrel{8}{8} \\
\stackrel{0}{\circ}\end{array}$ & \begin{tabular}{|l|}
$\stackrel{*}{*}$ \\
$\stackrel{*}{*}$ \\
$\dot{m}$ \\
$\dot{n}$
\end{tabular} & $\begin{array}{l}* \\
\stackrel{*}{*} \\
\infty \\
\infty \\
\dot{m}\end{array}$ & 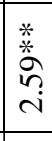 & 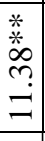 & & & & & $\begin{array}{l}0 \\
0 \\
0\end{array}$ & $\begin{array}{l}\stackrel{*}{*} \\
= \\
=\end{array}$ & \begin{tabular}{l}
$\stackrel{*}{*}$ \\
$\stackrel{*}{ \pm}$ \\
\hdashline
\end{tabular} & & & $\begin{array}{l}\tilde{O} \\
0 \\
0\end{array}$ & $\stackrel{m}{0}$ & & \\
\hline & $\overrightarrow{\mathbf{z}}$ & & $\stackrel{9}{\circ}$ & $\mid \begin{array}{c}* \\
\stackrel{*}{*} \\
\stackrel{m}{r} \\
\end{array}$ & 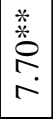 & 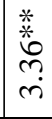 & 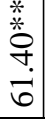 & & & & & $=$ & $\begin{array}{l}\stackrel{*}{*} \\
\stackrel{\sim}{\sim} \\
\stackrel{.}{-}\end{array}$ & $\begin{array}{l}\% \\
\stackrel{*}{*} \\
\hat{i} \\
\text { i }\end{array}$ & & & $\begin{array}{l} \pm \\
0 \\
0\end{array}$ & $\stackrel{8}{\circ}$ & & \\
\hline \multirow{3}{*}{$\Xi$} & u & 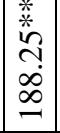 & $\frac{0}{0}$ & $\mid \begin{array}{c}* \\
* \\
\infty \\
i \\
i\end{array}$ & \begin{tabular}{l}
$*$ \\
\multirow{2}{*}{} \\
$\infty$ \\
$\dot{n}$ \\
$\dot{n}$
\end{tabular} & 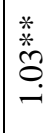 & 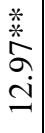 & 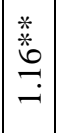 & 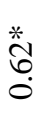 & 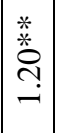 & $\begin{array}{l}\stackrel{*}{*} \\
\hat{ث} \\
\end{array}$ & $\stackrel{0}{0}$ & $\left|\begin{array}{c}* \\
\stackrel{*}{*} \\
\stackrel{n}{0} \\
0\end{array}\right|$ & 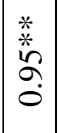 & $\mid$\begin{tabular}{l}
$*$ \\
\multirow{*}{*}{} \\
$\tilde{n}$ \\
0 \\
0
\end{tabular} & 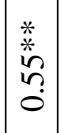 & $\begin{array}{l}0 \\
\vdots \\
0\end{array}$ & $\stackrel{t}{0}$ & & $\stackrel{\infty}{n}$ \\
\hline & $\tilde{z}$ & & $\overrightarrow{\widetilde{\sigma}}$ & \begin{tabular}{|l|} 
\\
$\stackrel{*}{*}$ \\
$\stackrel{*}{*}$ \\
\end{tabular} & $\begin{array}{l}* \\
\stackrel{*}{*} \\
0 \\
\dot{i} \\
\end{array}$ & 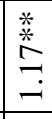 & 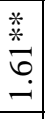 & & & & & $\stackrel{7}{0}$ & \begin{tabular}{|l|}
$*$ \\
$\stackrel{*}{*}$ \\
0 \\
\end{tabular} & \begin{tabular}{l}
$*$ \\
\multirow{*}{*}{} \\
$\tilde{n}$ \\
$\vdots$
\end{tabular} & & & $\begin{array}{l} \pm \\
0 \\
0\end{array}$ & 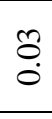 & & \\
\hline & $\overline{\mathbf{z}}$ & & $\stackrel{ }{\circ}$ & $\mid$\begin{tabular}{l}
$*$ \\
\multirow{*}{*}{} \\
$\hat{n}$ \\
$i$
\end{tabular} & $\begin{array}{l}\stackrel{*}{*} \\
\stackrel{*}{\sigma} \\
\dot{+} \\
\dot{+}\end{array}$ & 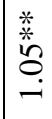 & 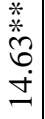 & & & & & $\overrightarrow{\tilde{\sigma}}$ & 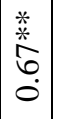 & $\begin{array}{l}* \\
\stackrel{*}{*} \\
\stackrel{\circ}{0}\end{array}$ & & & $\begin{array}{l}0 \\
0 \\
0\end{array}$ & $\stackrel{\partial}{\circ}$ & & \\
\hline \multirow{3}{*}{$\frac{\vec{E}}{\underline{\underline{E}}}$} & u & 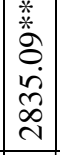 & $\begin{array}{l}\infty \\
\stackrel{1}{0} \\
0\end{array}$ & $\begin{array}{l}\stackrel{*}{*} \\
\stackrel{\sim}{\sim} \\
\stackrel{+}{*}\end{array}$ & 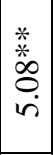 & $\begin{array}{l}\stackrel{*}{*} \\
\stackrel{*}{\sigma} \\
\stackrel{i}{\sim}\end{array}$ & $\begin{array}{l}\text { 羊 } \\
\infty \\
\stackrel{2}{c} \\
\dot{v} \\
m\end{array}$ & $\mid \begin{array}{c}* \\
\stackrel{*}{*} \\
\stackrel{0}{n} \\
\dot{n}\end{array}$ & 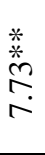 & $\begin{array}{l}\vec{*} \\
\hat{\sigma} \\
\dot{m} \\
\dot{m}\end{array}$ & $\begin{array}{l}\stackrel{*}{*} \\
\stackrel{+}{*} \\
\text { c }\end{array}$ & $\frac{\infty}{0}$ & $\left|\begin{array}{c}* \\
\stackrel{*}{*} \\
\infty \\
i \\
i\end{array}\right|$ & 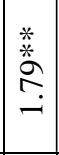 & 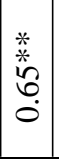 & 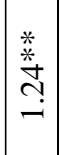 & $\begin{array}{l}0 \\
0 \\
0\end{array}$ & ণึ & & 官 \\
\hline & $\mathbf{z}$ & & in & 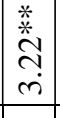 & $\begin{array}{l}\frac{*}{*} \\
\stackrel{*}{*} \\
\dot{\sigma} \\
\end{array}$ & 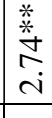 & 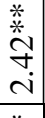 & & & & & 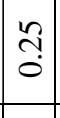 & 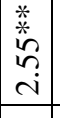 & \begin{tabular}{l}
$*$ \\
\multirow{2}{*}{} \\
$n$ \\
0 \\
0
\end{tabular} & & & $\begin{array}{l}\infty \\
0 \\
0\end{array}$ & ర్రి & & \\
\hline & $\vec{z}$ & & $\stackrel{0}{0}$ & $\begin{array}{l}* \\
\stackrel{*}{*} \\
\frac{0}{6}\end{array}$ & $\begin{array}{c}* \\
* \\
\dot{*} \\
\infty \\
\infty \\
\infty\end{array}$ & \begin{tabular}{l}
$*$ \\
\multirow{2}{*}{} \\
ते
\end{tabular} & \begin{tabular}{l}
$*$ \\
\multirow{*}{*}{} \\
$\infty$ \\
$\dot{j}$ \\
$\dot{f}$
\end{tabular} & & & & & $=$ & 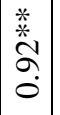 & \begin{tabular}{l}
$*$ \\
\multirow{*}{*}{} \\
$\stackrel{5}{f}$ \\
$i$
\end{tabular} & & & $\begin{array}{l} \pm \\
0 \\
0\end{array}$ & $\stackrel{n}{0}$ & & \\
\hline \multirow{3}{*}{ 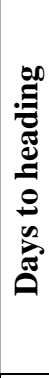 } & ט| & 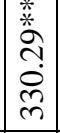 & $\begin{array}{l}: \\
:\end{array}$ & $\begin{array}{l}\stackrel{*}{*} \\
\stackrel{*}{*} \\
\stackrel{0}{0} \\
=\end{array}$ & 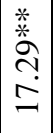 & 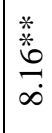 & 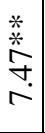 & 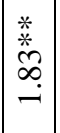 & 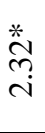 & 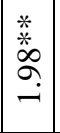 & $\begin{array}{l}\stackrel{0}{0} \\
\stackrel{0}{0}\end{array}$ & $\vec{\vdots}$ & $\mid \begin{array}{c}* \\
\stackrel{*}{0} \\
\\
m\end{array}$ & 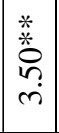 & 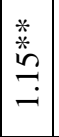 & 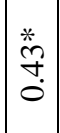 & ก̃ & $\stackrel{m}{0}$ & & $\stackrel{1}{0}$ \\
\hline & $\tilde{z}$ & & 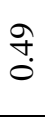 & 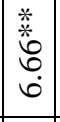 & $\begin{array}{l}\text { * } \\
\stackrel{*}{\mathrm{~N}} \\
\stackrel{i}{\mathrm{i}}\end{array}$ & 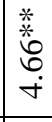 & 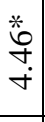 & & & & & $\begin{array}{l}\infty \\
\stackrel{0}{-} \\
\end{array}$ & 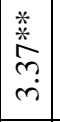 & \begin{tabular}{l}
$*$ \\
\multirow{*}{*}{} \\
$\stackrel{\infty}{\infty}$ \\
-
\end{tabular} & & & $\begin{array}{l}0 \\
\dddot{0} \\
0\end{array}$ & ֶ̃ & & \\
\hline & 表 & & $\begin{array}{l}m \\
\infty \\
0 \\
0\end{array}$ & \begin{tabular}{|} 
\\
$\stackrel{*}{*}$ \\
$\stackrel{*}{*}$ \\
$\dot{n}$
\end{tabular} & 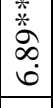 & \begin{tabular}{|l} 
萻 \\
$\dot{\sigma}$ \\
$\dot{n}$
\end{tabular} & 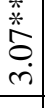 & & & & & 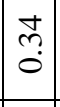 & 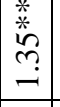 & 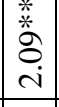 & & & $\overrightarrow{0}$ & $\stackrel{\infty}{\circ}$ & & \\
\hline \multirow[t]{2}{*}{ 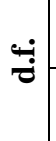 } & U & - & $\nabla$ & సิ & 10 & \pm & - & 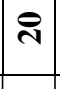 & 10 & $\mathbf{\Xi}$ & -1 & $\infty$ & 10 & 12 & 10 & 12 & 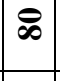 & & & \\
\hline & os & & $N$ & নิ & 10 & \pm & -1 & & & & & $\mathcal{F}$ & in & 12 & & & $\mathcal{F}$ & & & \\
\hline & فे & 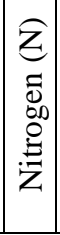 & 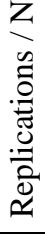 & $\left|\begin{array}{c}0 \\
0 \\
0 \\
0 \\
0 \\
0 \\
0 \\
0 \\
0 \\
0\end{array}\right|$ & 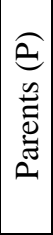 & $\begin{array}{l}\tilde{U} \\
\tilde{D} \\
\tilde{D} \\
0 \\
0\end{array}$ & $\begin{array}{l}u \\
\dot{D} \\
\vec{D}\end{array}$ & $\left|\begin{array}{l}z \\
x \\
x \\
0\end{array}\right|$ & $\begin{array}{l}Z_{x} \\
x \\
a\end{array}$ & $\begin{array}{l}z \\
x \\
u \\
u\end{array}$ & $\begin{array}{c}Z \\
x \\
u \\
\dot{D} \\
\dot{a} \\
\dot{a}\end{array}$ & 㫄 & ত্ঠ & 芯 & 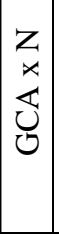 & $\mid \begin{array}{l}Z \\
x \\
\tilde{u} \\
u \\
w\end{array}$ & 节 & 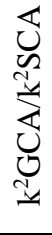 & 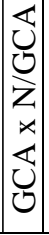 & 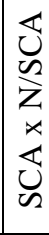 \\
\hline
\end{tabular}



Crosses of Bread Wheat under Nitrogen Stressed Conditions

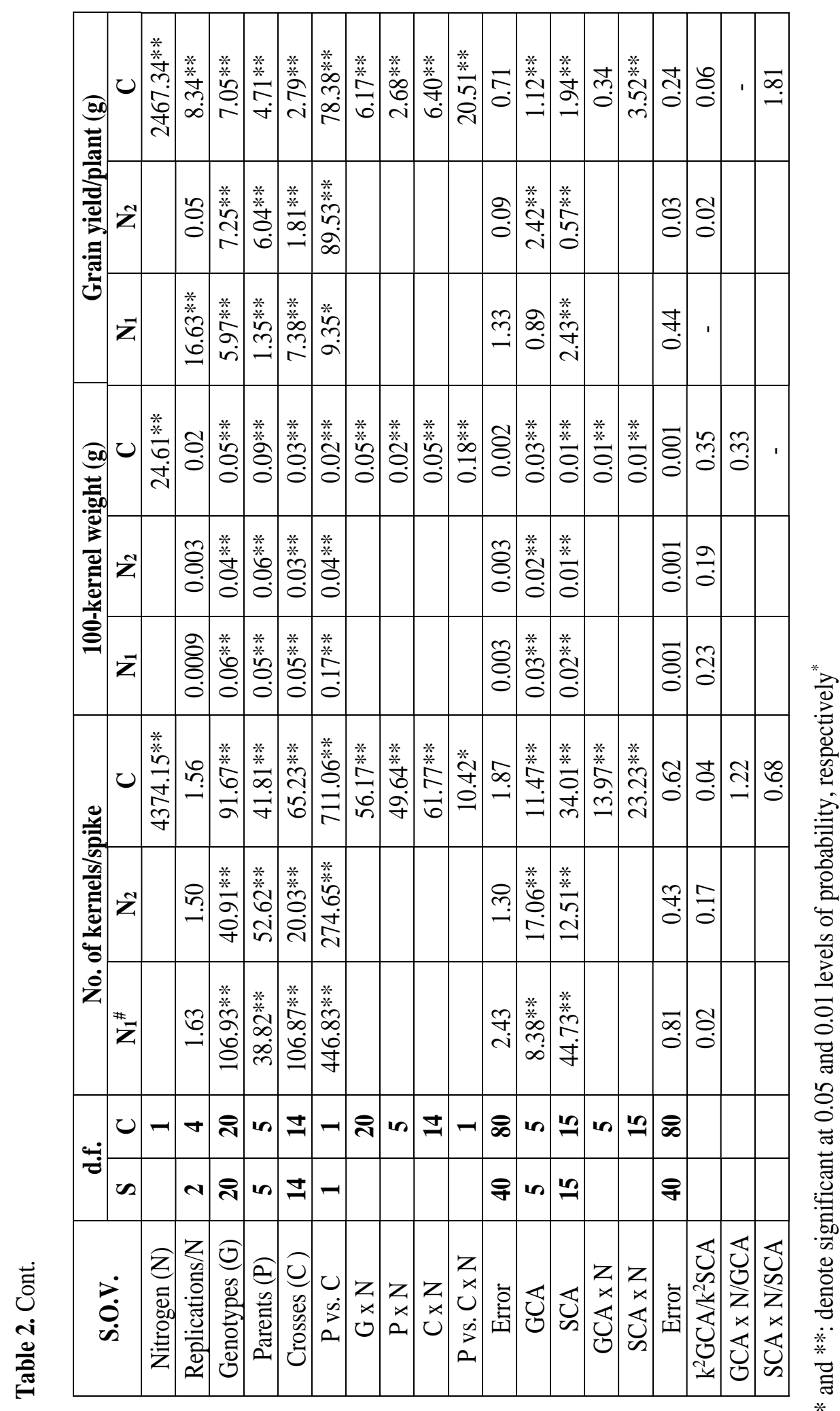


Mean squares due to parents vs. crosses were significant for all studied characters at both nitrogen levels, indicating that average heterosis overall crosses was pronounced for the studied characters under such environments. Interaction of genotypes $\mathrm{x} \mathrm{N}$-levels was highly significant for all studied characters, suggesting that the genotypes responded in a different way from one environment to another. Moreover, interaction of parents vs. crosses with $\mathrm{N}$ levels was significant for most studied characters, suggesting that heterosis differed from nitrogen level to another.

\subsection{Estimates of combining ability}

Partitioning sum of squares of genotypes into general and specific combining abilities for the studied characters under recommendedand $\mathrm{N}$-stress conditions are illustrated in (Table 2). Significant mean squares due to general and specific combining abilities were detected for all studied characters in both environments. Therefore, it seemed that both additive and non-additive genetic effects were operative for these characters. These results are in coincidence with those findings of (Haridy and Abd El-Zaher 2015). Ratios of GCA/SCA variances for the all studied characters were less than unity at both nitrogen levels. Such result indicates that inheritance of these traits was mainly controlled by non-additive gene effects under such conditions of nitrogen fertilization. These results are supported findings of (Motawea 2017; Farooq et al 2019; Kutlu and Sirel 2019). Mean squares for interactions of either GCA or SCA with nitrogen levels were highly significant for the all studied characters except of GCA x N levels for grain yield/plant, revealing the existence of sensitivity of both types of gene action to variation in nitrogen treatments. Such results indicate that nitrogen fertilization is considered as an effective factor for declaring GCA and SCA variances for these characters. Thus, the breeder should utilize the appropriate breeding method under each environment for developing desirable wheat genotypes. These findings are in harmony with those obtained by (El-Hosary et al 2012; Saleh and Mohamed 2016). GCA x N/GCA ratios were higher than SCA x N/SCA for days to heading, No. of spikes/plant, No. of kernels/spike and weight of 100-kernels, indicating higher sensitivity of additive gene effects to nitrogen levels than that of non-additive ones for these characters.

\subsection{Combining ability effects}

\subsubsection{General combining ability effects}

Effects of general combining ability $\left(\hat{\mathrm{g}}_{\mathrm{i}}\right)$ for individual parental genotypes in each trait under two nitrogen levels are given in (Table 3). Since, negative general combining ability effects were important for days to heading and the most desirable GCA effects were observed for cv. Giza 168 under two-N levels and cv. Sids 12 under N-stress conditions. These parents accumulated favorable alleles for earliness, which considered as best general combiners for breeding earlier genotypes under such conditions. While, cv. Misr 1 at two nitrogen levels and Line 36 under N-stress conditions proved to be poor combiners, which attained positive general combining ability effectstowards lateness.

Regarding plant height, cv. Sakha 93 under two $\mathrm{N}$ treatments, cv. Misr 1 under recommended N level and cv. Giza 168 under Nstress conditions had significant positive GCA effects, which appeared to be best combiners for developing taller genotypes under such environments. On contrast, significant negative GCA effects were detected in introduced cv. Cham 4 under two N levels and cv. Sids 12 under N-stress conditions, indicating that these parents behaved as good combiners for developing shorter genotypes under such environments. Concerning number of spikes/plant, cvs.; Sakha 93, Sids 12 and Misr 1 under recommended $\mathrm{N}$ level as well as cv. Cham 4 and Line 36 under $\mathrm{N}$ stress conditions had significant positive GCA effects, which were the best 

Crosses of Bread Wheat under Nitrogen Stressed Conditions

Table 3. General combining ability effects ( $\mathrm{g} i)$ estimates of the six parents for the studied characters under recommended $\left(\mathrm{N}_{1}\right)$ and $\operatorname{low}\left(\mathrm{N}_{2}\right)$ nitrogen fertilization levels

\begin{tabular}{|c|c|c|c|c|c|c|c|c|}
\hline \multirow{2}{*}{ Parents } & \multicolumn{2}{|c|}{ Days to heading } & \multicolumn{2}{|c|}{$\begin{array}{l}\text { Plant height } \\
\text { (cm) }\end{array}$} & \multicolumn{2}{|c|}{$\begin{array}{c}\text { Spike length } \\
(\mathbf{c m})\end{array}$} & \multicolumn{2}{|c|}{$\begin{array}{c}\begin{array}{c}\text { No. of } \\
\text { spikes/plant }\end{array} \\
\end{array}$} \\
\hline & $N_{1}$ & $\mathbf{N}_{2}$ & $\mathbf{N}_{\mathbf{1}}$ & $\mathbf{N}_{2}$ & $\mathbf{N}_{1}$ & $\mathbf{N}_{2}$ & $\mathbf{N}_{1}$ & $\mathbf{N}_{2}$ \\
\hline Cham 4 & 0.03 & -0.01 & $-0.56^{* *}$ & $-0.69 * *$ & $-0.39 * *$ & 0.09 & -0.08 & $0.45^{* *}$ \\
\hline Giza 168 & -0.60 ** & $-0.72 * *$ & 0.02 & $0.34 * *$ & $0.31 * *$ & 0.10 & -0.09 & $-0.35^{* *}$ \\
\hline Line 36 & -0.18 & $0.69 * *$ & -0.11 & 0.19 & 0.16 & 0.03 & $-0.73 * *$ & $0.46 * *$ \\
\hline Sakha 93 & -0.06 & -0.14 & $0.36 * *$ & $0.78 * *$ & 0.12 & $-0.15^{*}$ & $0.26 * *$ & $-0.38 * *$ \\
\hline Sids 12 & 0.15 & $-0.64 * *$ & -0.06 & $-0.59 * *$ & 0.15 & $0.14^{*}$ & $0.51 * *$ & $-0.13 * *$ \\
\hline Misr 1 & $0.65 * *$ & $0.82 * *$ & $0.35 * *$ & -0.02 & $-0.34 * *$ & $-0.21 * *$ & $0.13^{*}$ & -0.05 \\
\hline L.S.D.0.05( $\left(\mathrm{g}_{\mathrm{i}}\right)$ & 0.22 & 0.39 & 0.12 & 0.19 & 0.17 & 0.13 & 0.13 & 0.09 \\
\hline $0.01\left(\mathrm{~g}_{\mathrm{i}}\right)$ & 0.30 & 0.52 & 0.16 & 0.25 & 0.23 & 0.18 & 0.17 & 0.13 \\
\hline $0.05\left(\mathrm{~g}_{\mathrm{i}}-\mathrm{g}_{\mathrm{j}}\right)$ & 0.34 & 0.61 & 0.19 & 0.29 & 0.26 & 0.20 & 0.20 & 0.15 \\
\hline $0.01\left(\mathrm{~g}_{\mathrm{i}}-\mathrm{g}_{\mathrm{j}}\right)$ & 0.46 & 0.81 & 0.26 & 0.39 & 0.35 & 0.27 & 0.26 & 0.20 \\
\hline
\end{tabular}

Table 3. Cont.

\begin{tabular}{|l|c|c|c|c|c|c|}
\hline \multirow{2}{*}{ Parents } & \multicolumn{2}{|c|}{ No. of kernels/spike } & \multicolumn{2}{c|}{$\begin{array}{c}\text { 100-kernel weight } \\
\text { (g) }\end{array}$} & \multicolumn{2}{c|}{$\begin{array}{c}\text { Grain yield/plant } \\
\text { (g) }\end{array}$} \\
\cline { 2 - 7 } & $\mathbf{N}_{\mathbf{1}}$ & $\mathbf{N}_{\mathbf{2}}$ & $\mathbf{N}_{\mathbf{1}}$ & $\mathbf{N}_{\mathbf{2}}$ & $\mathbf{N}_{\mathbf{1}}$ & $\mathbf{N}_{\mathbf{2}}$ \\
\hline Cham 4 & $1.73 * *$ & 0.24 & -0.06 & $-0.04 * *$ & -0.01 & -0.04 \\
\hline Giza 168 & -0.18 & $0.70 * *$ & $0.07 *$ & $0.03 * *$ & 0.00 & -0.10 \\
\hline Line 36 & -0.10 & $0.69 * *$ & -0.05 & $0.04 * *$ & -0.05 & $0.14 *$ \\
\hline Sakha 93 & $-0.99 * *$ & $1.88^{* *}$ & 0.02 & $0.06 * *$ & -0.06 & $0.45 * *$ \\
\hline Sids 12 & 0.52 & $-1.73 * *$ & -0.03 & $-0.05 * *$ & $0.41 *$ & $-0.12 *$ \\
\hline Misr 1 & $-0.99 * *$ & $-1.77 * *$ & 0.04 & $-0.03 * *$ & -0.29 & $-0.33 * *$ \\
\hline L.S.D. 0.05 (gi) & 0.59 & 0.43 & 0.06 & 0.02 & 0.11 & 0.36 \\
\hline 0.01 (gi) & 0.79 & 0.57 & 0.09 & 0.03 & 0.15 & 0.48 \\
\hline 0.05 (gi-gj) & 0.91 & 0.66 & 0.02 & 0.11 & 0.17 & 0.67 \\
\hline 0.01 (gi-gj) & 1.22 & 0.89 & 0.03 & 0.14 & 0.90 & 0.23 \\
\hline
\end{tabular}

* and $* *$ denote significant at 0.05 and 0.01 levels of probability, respectively. ${ }^{*}$ 
among the parental set as progenitors in breeding programs to improve this character under such conditions. On the contrary, Line 36 under recommended N level and cvs.; Giza 168, Sakha 93 and Sids 12 under N-stress conditions, were the worse combiners for this character. In continuous, spike length revealed that, cv. Giza 168 under recommended nitrogen treatment and cv. Sids 12 under N-stress conditions seemed to be the best combiners, as they exhibited significant positive $\left(\hat{\mathrm{g}}_{\mathrm{i}}\right)$ estimates, indicating great value of such parents as promising progenitors for high expression of this character. Whereas, cv. Misr 1 under two $\mathrm{N}$ levels, cv. Cham 4 under recommended nitrogen level and cv. Sakha 93 under N-stress conditions were considered poor combiners. For number of kernels/spike, cv. Cham 4 under recommended N level and parents; Sakha 93, Giza 168 and Line 36 under N-stress conditions had significant and positive GCA effects. Whereas cv. Misr 1 under two nitrogen levels, cv. Sakha 93 under recommended $\mathrm{N}$ level and cv. Sids 12 under $\mathrm{N}$-stress conditions gave negative $\left(\hat{g}_{\mathrm{i}}\right)$ estimates. Promising general combiners for 100-kernel weight were cv. Giza 168 under both $\mathrm{N}$ levels as well as cv. Sakha 93 and the Line 36 under $\mathrm{N}$-stress conditions as they exhibited significant and positive GCA effects. While, significant negative $\left(\hat{g}_{i}\right)$ values were observed in cvs.; Cham 4, Sids 12 and Misr 1 under N-stress conditions for this character. Regarding grain yield/plant, cv. Sids 12 under recommended $\mathrm{N}$ treatment as well as cv. Sakha 93 and Line 36 under N-stress conditions showed significant and positive GCA effects, which indicated their superiority as promising progenitors for high yielding ability. On the other hand, cvs.; Sids 12 and Misr 1 under $\mathrm{N}$-stress conditions were poor combiners for this character as shown from their significant and negative GCA effects.

In light of previous results, it could be concluded that cv. Sakha 93 was best combiner for grain yield and most related characters under $\mathrm{N}$-stress conditions, which had favorable alleles, thus improvement of grain yield can be achieved by its use in breeding program. On the other hand, the parents, which showed high $\left(\hat{\mathrm{g}}_{\mathrm{i}}\right)$ estimates for one or more of yield components may not necessarily had high $\left(\hat{g}_{\mathrm{i}}\right)$ estimates for grain yield.

Correlations between performance of parents and their $\left(\hat{g}_{\mathrm{i}}\right)$ values under low $\mathrm{N}$ level were significant positive for all studied characters except spike length trait (Table 5), revealing that performance ofparents reflects their behavior in cross combinations.

\subsubsection{Specific combining ability effects}

Results for specific combining ability effects $\left(\hat{\mathrm{s}}_{\mathrm{ij}}\right)$ presented in Table 4 indicated that four crosses; Cham 4 x Sakha 93, Cham $4 \mathrm{x}$ Misr 1, Line 36 x Sakha 93 and Sakha 93 x Misr 1 under two $\mathrm{N}$ levels as well as the four crosses; Cham 4 x Giza 168, Cham 4 x Line 36, Giza 168 x Line 36 and Giza 168 x Sakha 93 under recommended $\mathrm{N}$ level and two crosses; Line 36 x Sids 12 and Sids 12 x Misr 1 under $\mathrm{N}$ stress conditions had significant negative $\left(\hat{\mathrm{s}}_{\mathrm{ij}}\right)$ values for days to heading, towards earliness. Therefore, the abovementioned crosses were of great importance in wheat breeding programs for improvement this trait. On the other hand, four crosses; Cham 4 x Sids 12, Giza 168 x Sids 12, Giza 168 x Misr 1 and Line $36 \mathrm{x}$ Misr 1 at both $\mathrm{N}$ levels as well as cross Line $36 \mathrm{x}$ Sids 12 under recommended $\mathrm{N}$ level and cross Sakha 93 x Sids 12 under low-N conditions showed significant positive SCA effects for days to heading, towards lateness under such conditions. Plant height showed significant positive $\left(\hat{\mathrm{s}}_{\mathrm{ij}}\right)$ values in five crosscombinations; Cham 4 x Giza 168, Cham 4 x Sids 12, Line 36 x Sids 12, Sakha 93 x Sids 12 and Sakha $93 \times$ Misr 1 at both $\mathrm{N}$ levels and seven crosses; Cham 4 x Sakha 93, Cham 4 x Misr 1, Giza 168 x Line 36, Giza 168 x Sids 12, Giza 168 x Misr 1, Line 36 x Sakha 93 and sids $12 \times$ Misr 1 under recommended $\mathrm{N}$ level. While, significant negative $\left(\hat{\mathrm{s}}_{\mathrm{ij}}\right)$ estimates were observed in three crosses; Cham 4 x Sakha 93, Giza 168 x Sids 12 and Line 36 x Sakha 93 for this trait under $\mathrm{N}$-stress conditions. Regarding number of spikes/plant, seven crosses; Cham 4 x Line 36, Cham 4 x Sakha 93, Cham 4 x Sids 12, Giza 168 x Sids 12, Giza 168 x Misr 1, Line 


\section{Combining Ability for Grain Yield and Some Agronomic Traits in Diallel Crosses of Bread Wheat under Nitrogen Stressed Conditions}

36 x Sakha 93 and Sids 12 x Misr 1 at both N levels, five crosses; Cham 4 x Giza 168, Cham 4 x Misr 1, Giza 168 x Line 36, Giza 168 x Sakha 93 and Line 36 x Sids 12 under recommended N level and cross Sakha 93 x Sids 12 under $\mathrm{N}$-stress conditions gave significant positive $\left(\hat{\mathrm{S}}_{\mathrm{ij}}\right)$ values. Whereas, Line $36 \mathrm{x}$ Misr 1 cross at both N levels, two crosses; Sakha $93 \mathrm{x}$ Sids 12 and Sakha 93 x Misr 1 under recommended $\mathrm{N}$ level and four crosses; Cham $4 \mathrm{x}$ Giza 168, Cham 4 x Misr 1, Giza 168 x Sakha 93 and Line 36 x Sids 12 under N-stress conditions gave significant negative $\left(\hat{s}_{i j}\right)$ estimates. Spike length revealed significant positive $\left(\hat{\mathrm{s}}_{\mathrm{ij}}\right)$ values in three crosses; Cham 4x Giza 168, Cham 4 x Misr 1 and Giza 168 x Misr 1 at both N levels, five crosses; Cham 4 x Sids 12, Giza 168 x Line 36, Line 36 x Sids 12, Line 36 x Misr 1 and Sakha 93 x Misr 1 under recommended $\mathrm{N}$ level and four crosses; Cham $4 \mathrm{x}$ Line 36, Cham 4 x Sakha 93, Line 36 x Sakha 93 and Sids $12 \times$ Misr 1 under N-stress conditions. On the other hand, significant negative $\left(\hat{\mathrm{s}}_{\mathrm{ij}}\right)$ estimates were obtained in two crosses; Cham 4 x Line 36 and Giza 168x Sids 12 under recommended $\mathrm{N}$ level and four crosses; Cham 4 x Sids 12, Giza 168 x Line 36, Giza 168 x Sakha 93 and Sakha 93 x Sids 12 under Nstress conditions. Therefore, these crosses are considered as poor $\mathrm{F}_{1}$-cross combinations for this trait. Regarding number of kernels/spike, four crosses; Cham 4 x Misr 1, Giza 168 x Line 36, Giza 168 x Sids 12 and Sakha 93 x Sids 12 at both N levels, three crosses; Cham $4 \times$ Sakha 93, Giza 168 x Sakha 93 and Line 36 x Sakha 93 under recommended $\mathrm{N}$ level and six crosses; Cham 4 x Giza 168, Cham 4 x Line 36, Cham 4 x Sids 12, Giza 168 x Misr 1, Sakha 93 x Misr 1 and Sids 12 x Misr 1 under $\mathrm{N}$-stress conditions expressed significant positive $\left(\hat{\mathrm{S}}_{\mathrm{ij}}\right)$ values, which were considered as good $\mathrm{F}_{1}$-cross combinations for this trait under such conditions. On the other hand, significant negative $\left(\hat{\mathrm{S}}_{\mathrm{ij}}\right)$ estimates were registered in five crosses; Cham 4 x Giza 168, Cham 4 x Sids 12, Giza 168 x Misr 1, Line 36 x Sids 12 and Sids
$12 \times$ Misr 1 under recommended $\mathrm{N}$ level and three crosses; Cham 4 x Sakha 93, Giza 168 x Sakha 93 and Line 36 x Misr 1 under N-stress conditions for this trait. With respect to 100kernel weight, wheat cross Cham 4 x Giza 168 under two N levels, Giza 168 x Misr 1 under recommended $\mathrm{N}$ level and seven crosses; Cham 4 x Line 36, Cham 4 x Sids 12, Giza 168 x Sids 12, Line 36 x Sakha 93, Sakha 93 x Sids 12, Sakha 93 x Misr 1 and Sids 12 x Misr 1 under $\mathrm{N}$-stress conditions showed significant positive $\left(\hat{\mathrm{s}}_{\mathrm{ij}}\right)$ estimates. However, significant negative $\left(\hat{\mathrm{s}}_{\mathrm{ij}}\right)$ values were recorded in Line 36 $\mathrm{x}$ Misr 1 at both $\mathrm{N}$ levels, three crosses; Giza $168 \times$ Line 36, Line 36 x Sakha 93 and Sakha $93 \times$ Sids 12 under recommended $\mathrm{N}$ level and two crosses; Cham 4 x Sakha 93 and Giza 168 x Sakha 93 under N-stress conditions. Grain yield/plant showed significant desirable $\left(\hat{\mathrm{s}}_{\mathrm{ij}}\right)$ estimates in Cham 4 x Sids 12, Cham 4 x Misr 1, Giza 168 x Sids 12, Giza 168 x Misr 1 and Line $36 \times$ Misr 1 under both $\mathrm{N}$ levels as well as two crosses; Giza 168 x Sakha 93 and Line 36 x Sakha 93 under recommended $N$ level and seven crosses; Cham 4 x Giza 168, Cham 4 x Line 36, Giza 168 x line 36, Line 36 x Sids 12, Sakha 93 x Sids 12, Sakha 93 x Misr 1 and Sids $12 \times$ Misr 1 under N-stress conditions for increasing grain yield. On the contrary, significant negative $\left(\hat{\mathrm{s}}_{\mathrm{ij}}\right)$ values were observed in Line 36 x Sids 12, Sakha 93 x Misr 1 and Sids 12 x Misr 1 under recommended $\mathrm{N}$ level and three crosses; Cham 4 x Sakha 93, Giza 168 x Sakha 93 and Line 36 x Sakha 93 under N-stress conditions. From above mentioned results, it could be concluded that the highest specific cross combinations for grain yield under N-stress conditions were Cham 4 x Giza 168and Sids $12 \mathrm{x}$ Misr 1. In such cross combinations, desirable transgressive segregants could be expected in subsequent segregating generations. Therefore, these crosses are valuable in wheat breeding programs for improving grain yield under low $\mathrm{N}$ level. Such results were in coincidence with those obtained by (Al-Naggar et al 2017b; El-Said 2018). 
Table 4. Specific combining ability effects $\left(\hat{\mathrm{s}}_{\mathrm{ij}}\right)$ estimates of the studied characters for $15 \mathrm{~F}_{1}$ crosses at recommended $\left(\mathrm{N}_{1}\right)$ and low $\left(\mathrm{N}_{2}\right)$ nitrogen fertilization levels

\begin{tabular}{|c|c|c|c|c|c|c|c|c|}
\hline \multirow{2}{*}{ Crosses } & \multicolumn{2}{|c|}{ Days to heading } & \multicolumn{2}{|c|}{$\begin{array}{l}\text { Plant height } \\
(\mathbf{c m})\end{array}$} & \multicolumn{2}{|c|}{ Spike length $(\mathbf{c m})$} & \multicolumn{2}{|c|}{ No. of spikes/plant } \\
\hline & $\mathbf{N}_{1}$ & $\mathbf{N}_{2}$ & $\mathbf{N}_{1}$ & $\mathbf{N}_{2}$ & $\mathbf{N}_{1}$ & $\mathbf{N}_{2}$ & $\mathbf{N}_{1}$ & $\mathbf{N}_{2}$ \\
\hline Cham 4 x Giza 168 & $-0.30 *$ & -0.23 & $38 * *$ & $1.83 * *$ & $1.15^{* * *}$ & $.48 * *$ & $0.35 * *$ & $-0.94 * *$ \\
\hline Cham 4 x Line 36 & $.72 * *$ & -0.32 & 0.09 & 0.10 & $-0.37 * *$ & $0.65 * *$ & $2.05 * *$ & $1.06 * *$ \\
\hline Cham 4 x Sakha 93 & $-0.85 * *$ & $-1.82 * *$ & $0.52 * *$ & $-1.36^{* *}$ & -0.13 & $1.02 * *$ & $1.46 * *$ & $0.52 * *$ \\
\hline Cham 4 x Sids 12 & $0.95 * *$ & & $1.30 * *$ & $0.32 *$ & $0.33 * *$ & $-0.53 * *$ & $1.60 * *$ & $1.03 * *$ \\
\hline Cham 4 x Mi & & & & 0.07 & & & $00 * *$ & $-0.89 * *$ \\
\hline Giza $168 \times$ L Line 36 & $.10 * *$ & -0.27 & $1.22 * *$ & -0.06 & $0.60 * *$ & $-0.27 * *$ & $.56^{* *}$ & -0.01 \\
\hline Giza 168 x Sakha 93 & $-0.55 * *$ & -0.11 & -0.01 & 0.22 & -0.10 & $-1.18 * *$ & $1.47 * *$ & $-0.88 * *$ \\
\hline Giza 168 x Sids 12 & $1.24 * *$ & $0.73 * *$ & $1.08 * *$ & $-0.80 * *$ & $-0.39 * *$ & 0.12 & $1.33 * *$ & $1.53 * *$ \\
\hline Giza 168 x Misr 1 & $2.07 * *$ & $2.27 * *$ & $1.37 * *$ & -0.16 & $1.11 * *$ & $0.18^{*}$ & $0.40 * *$ & $0.80 * *$ \\
\hline Line 36 x Sakha 93 & $-1.64 * *$ & $-1.19 * *$ & $1.56^{* *}$ & $-0.32 *$ & -0.17 & $0.71 * *$ & $0.67 * *$ & $0.46 * *$ \\
\hline Line 36 x Sids 12 & $0.82 * *$ & $-1.02 * *$ & $0.41 * *$ & $0.29 *$ & $1.06 * *$ & -0.08 & $1.00 * *$ & $-0.78 * *$ \\
\hline Line 36 x Misr 1 & $1.65 * *$ & 0.85 & 0.09 & 0.03 & $0.25^{*}$ & 0.1 & $-0.57 * *$ & $-0.23 * *$ \\
\hline Sakha $93 \times$ Sids 12 & & * & $0.65 * *$ & $1.21 * *$ & 0.14 & $-1.01 * *$ & $-2.06 * *$ & $0.94 * *$ \\
\hline Sakha 93 x Misr 1 & $-1.47 * *$ & $-0.98 * *$ & $1.11 * *$ & $0.54 * *$ & $1.12 * *$ & 0.17 & $-0.55 * *$ & 0.03 \\
\hline Sids 12 x Misr 1 & -0.01 & $-1.48 * *$ & $0.62 * *$ & -0.06 & 0.19 & $0.41 * *$ & $0.86 * *$ & $1.39 * *$ \\
\hline L.S.D. $5 \%$ & 0.29 & 0.51 & 0.16 & 0.24 & 0.22 & 0.17 & 0.16 & 0.12 \\
\hline & 0.39 & 0.68 & 0.21 & 0.33 & 0.30 & 0.23 & 0.22 & 0.17 \\
\hline
\end{tabular}

Table 4.Cont.

\begin{tabular}{|l|c|c|c|c|c|c|}
\hline \multicolumn{1}{|c|}{ Crosses } & \multicolumn{2}{|c|}{ No. of kernels/spike } & \multicolumn{2}{c|}{ 100-kernel weight (g) } & \multicolumn{2}{c|}{ Grain yield/plant (g) } \\
\hline & $\mathrm{N}_{1}$ & $\mathrm{~N}_{2}$ & $\mathrm{~N}_{1}$ & $\mathrm{~N}_{2}$ & $\mathrm{~N}_{1}$ & $\mathrm{~N}_{2}$ \\
\hline Cham 4 x Giza 168 & $-2.98^{* *}$ & $5.21^{* *}$ & $0.12^{* *}$ & $0.23^{* *}$ & 0.26 & $2.43^{* *}$ \\
\hline Cham 4 x Line 36 & -0.29 & $2.83^{* *}$ & -0.04 & $0.05^{* *}$ & 0.15 & $1.02^{* *}$ \\
\hline Cham 4 x Sakha 93 & $4.74^{* *}$ & $-1.08^{* *}$ & -0.02 & $-0.16^{* *}$ & 0.24 & $-0.50^{* *}$ \\
\hline Cham 4 x Sids 12 & $-1.67^{* *}$ & $2.44^{* *}$ & -0.02 & $0.05^{* *}$ & $0.88^{* *}$ & $0.75^{* *}$ \\
\hline Cham 4 x Misr 1 & $18.95^{* *}$ & $1.23^{* *}$ & -0.07 & -0.01 & $0.93^{* *}$ & $0.49^{* *}$ \\
\hline Giza 168 x Line 36 & $4.23^{* *}$ & $1.09^{* *}$ & $-0.13^{* *}$ & 0.02 & 0.29 & $1.54^{* *}$ \\
\hline Giza 168 x Sakha 93 & $1.90^{* *}$ & $-3.74^{* *}$ & 0.01 & $-0.14^{* *}$ & $0.53^{*}$ & $-0.38^{* *}$ \\
\hline Giza 168 x Sids 12 & $2.03^{* *}$ & $2.19^{* *}$ & -0.02 & $0.08^{* *}$ & $0.60^{*}$ & $0.82^{* *}$ \\
\hline Giza 168 x Misr 1 & $-6.41^{* *}$ & $1.07^{* *}$ & $0.10^{*}$ & -0.03 & $0.66^{* *}$ & $0.75^{* *}$ \\
\hline Line 36 x Sakha 93 & $2.15^{* *}$ & -0.16 & $-0.09^{*}$ & $0.04^{*}$ & $1.28^{* *}$ & $-0.63^{* *}$ \\
\hline Line 36 x Sids 12 & $-4.31^{* *}$ & 0.53 & 0.07 & -0.02 & $-1.18^{* *}$ & $0.28^{* *}$ \\
\hline Line 36 x Misr 1 & 0.72 & $-1.29^{* *}$ & $-0.09^{*}$ & $-0.13^{* *}$ & $0.51^{*}$ & $0.41^{* *}$ \\
\hline Sakha 93 x Sids 12 & $4.36^{* *}$ & $5.27 * *$ & $-0.11^{*}$ & $0.08^{* *}$ & 0.45 & $1.48^{* *}$ \\
\hline Sakha 93 x Misr 1 & -0.12 & $3.09^{* *}$ & -0.06 & $0.12^{* *}$ & $-1.26^{* *}$ & $0.66^{* *}$ \\
\hline Sids 12 x Misr 1 & $-1.93^{* *}$ & $1.13^{* *}$ & 0.05 & $0.06^{* *}$ & $-0.71^{* *}$ & $2.23^{* *}$ \\
\hline L.S.D. 5\% & 0.77 & 0.56 & 0.08 & 0.03 & 0.47 & 0.15 \\
\hline L.S.D. 1\% & 1.03 & 0.75 & 0.11 & 0.04 & 0.63 & 0.19 \\
\hline
\end{tabular}

$*$ and $* *$ indicate significant at 0.05 and 0.01 probability levels, respectively* 


\section{Combining Ability for Grain Yield and Some Agronomic Traits in Diallel Crosses of Bread Wheat under Nitrogen Stressed Conditions}

Table 5. Correlation coefficients between parental means $\left(X_{p}\right)$ and their $\bar{G} C A$ effects as well as between $F_{1}$ means $\left(\mathrm{X}_{\mathrm{F} 1}\right)$ and SCA effectsfor studied characters under recommended $\left(\mathrm{N}_{1}\right)$ and low $\left(\mathrm{N}_{2}\right)$ nitrogen levels

\begin{tabular}{|l|c|c|c|c|}
\hline \multirow{2}{*}{ Traits } & \multicolumn{2}{c|}{$\overline{\mathbf{X}_{\mathbf{p}}}$ vs. GCA effects } & \multicolumn{2}{c|}{$\overline{\mathbf{X}_{\mathbf{F 1}} \text { vs. SCA effects }}$} \\
\cline { 2 - 5 } & $\mathbf{\mathbf { N } _ { \mathbf { 1 } }}$ & $\mathbf{\mathbf { N } _ { \mathbf { 2 } }}$ & $\mathbf{N}_{\mathbf{1}}$ & $\mathbf{N}_{\mathbf{2}}$ \\
\hline 1- Days to heading & 0.314 & $0.886^{*}$ & $0.839^{* *}$ & $0.714^{* *}$ \\
\hline 2- Plant height (cm) & 0.029 & $0.943^{* *}$ & $0.668^{* *}$ & $0.575^{*}$ \\
\hline 3- Spike length (cm) & 0.600 & 0.771 & $0.643^{* *}$ & $0.886^{* *}$ \\
\hline 4- Number of spikes/plant & 0.657 & $0.829^{*}$ & $0.864^{* *}$ & $0.914^{* *}$ \\
\hline 5- Number of kernels/spike & 0.086 & $0.886^{*}$ & $0.764^{* *}$ & $0.721^{* *}$ \\
\hline 6- 100-kernel weight (g) & 0.714 & $1.000^{* *}$ & $0.586^{*}$ & $0.811^{* *}$ \\
\hline 7- Grain yield/plant (g) & 0.143 & $0.943^{* *}$ & $0.839^{* *}$ & $0.946^{* *}$ \\
\hline
\end{tabular}

$*$ and $* *$ indicate significant at 0.05 and 0.01 probability levels, respectively*

It is worthy to note that parents with high $\left(\hat{\mathrm{g}}_{\mathrm{i}}\right)$ estimates not necessary to have also crosses with high $\left(\hat{\mathrm{S}}_{\mathrm{ij}}\right)$ ones. In thecase of crosscombinations; Cham 4 x Sakha 93, Giza 168 x Sakha 93 and Line 36 x Sakha 93 for grain yield/plant involving parents with high $\left(\hat{\mathrm{g}}_{\mathrm{i}}\right)$ estimates (Sakha 93), gave comparatively very low $\left(\hat{\mathrm{S}}_{\mathrm{ij}}\right)$ ones. In this respect, (Motawea 2017; Shrief et al 2017) found that low values of $\left(\hat{s}_{\mathrm{ij}}\right)$ might be attributed to some internal cancellation of favorable factors or to genetic similarity of the involved parents. On contrast, both parents of crosses; Cham 4 x Line 36 and Giza 168 $\mathrm{x}$ Line 36 for grain yield plant ${ }^{-1}$, Giza $168 \mathrm{x}$ Sids 12, Sakha 93 x Sids 12 and Sids 12 x Misr 1 for 100-kernel weight and Giza 168 x Sakha 93, Line 36 x Sakha 93 and Sakha 93 x Sids 12 for number of kernels/spike, had low $\left(\hat{g}_{i}\right)$ estimates, but gave comparatively high $\left(\hat{\mathrm{S}}_{\mathrm{ij}}\right)$ estimates for such characters, which attributed to high genetic diversity among the parents. Similar results were registered by (Farooq et al 2019).

As shown in (Table 5), significant positive correlation coefficients were detected between crosses performance and their $\left(\hat{\mathrm{s}}_{\mathrm{ij}}\right)$ estimates for all characters at both nitrogen treatments. This result indicates that high specific combinations were also high performing crosses; consequently the good $\mathrm{F}_{1}$ crosses could be identified from their performance. In this respect, (Al-Naggar et al 2015b) reported that either $\left(\hat{\mathrm{S}}_{\mathrm{ij}}\right)$ estimates or their performance can be used to select the best crosses. Moreover, the existence of significant correlations between parental means and their $\left(\hat{\mathrm{g}}_{\mathrm{i}}\right)$ estimates as well as crosses means and their $\left(\hat{\mathrm{s}}_{\mathrm{ij}}\right)$ estimates for most traits may serve as useful tools for identifying potential parents and crosses at an early stage of the breeding program based on their phenotypic expression under the two nitrogen levels.

\section{References}

Al-Naggar, AMM; Shabana, R; Abd ElAleem, MM; El-Rashidy ZA (2015a) Assessment of N-efficiency and N-responsiveness of six wheat (Triticum aestivum L.) genotypes and their $F_{1}$ and $F_{2}$ diallel crosses. International Journal of Plant \& Soil Science 6, 1-21.

Al-Naggar, AMM; Shabana, R; Abd ElAleem, MM; El-Rashidy ZA (2015b) Per se performance and combining ability of six wheat genotypes and their $F_{1}$ diallel crosses for NUE traits under contrasting-N conditions. American Research Journal of Agriculture 1, 13-23.

Al-Naggar, AMM; Shabana, R; Abd ElAleem, MM; El-Rashidy, ZA (2017 a) Mode of inheritance of low-N tolerance adaptive traits in wheat (Triticum aestivum L.) under contrasting nitrogen environments. Spanish Journal of Agricultural Research 15, 1-11. 
Al-Naggar, AMM; Shabana, R; Abd ElAleem, MM; El-Rashidy, ZA (2017 b) Genetics of low-N tolerance adaptive traits in wheat (Triticum aestivum L.) under contrasting nitrogen environments. Spanish Journal of Agricultural Research 17, 82-97.

Ayoob, MH (2020) Combining ability analysis, estimation of heterosis and some genetic parameters using half diallel cross in bread wheat (Triticum aestivum L.). $J$ Edu and Sci 29, 93-106.

Bouwman, AF; Boumans, LJM; Batjes, NH (2002) Emissions of $\mathrm{N}_{2} \mathrm{O}$ and $\mathrm{NO}$ from fertilized fields: Summary of available measurement data. Global Biogeochemical Cycles 16, 1058.

El-Hosary, AA; El-Badawy, MEl; Ashoush, HA; El-Hosary, AAA; Yahya, AI (2012) Inheritance of yield and its components in $F_{1}$ Crosses of wheat using diallel crosses under three nitrogen rates. $J$ Plant production Mansoura Univ 3, 2001-2015.

El-Marakby, AM; Mohamed, AA; Yasein, M; Tolba, AM (1994) Heritability estimates and selection for high-yielding and early-heading recombinants in segregating generations of five wheat crosses. Ann Agric Sci Moshtohor 32, 1089-1106.

El-Said, ARR (2018) Assessment of genetical parameters of yield and its attributes in bread wheat (Triticum aestivum L.) J Agric Chem Biotech 9, 243- 251.

Farooq, MU; Ishaaq, I; Aqbool, RM; Aslam, I; Naqvi, SMTA; Mustafa, SE (2019) Heritability, genetic gain and detection of gene action in hexaploid wheat for yield and its related attributes. AIMS Agric and Food 4, 56-72.

Gomez, KA; Gomez, AA (1984) Statistical Procedures for Agricultural Research. $2^{\text {nd }}$ Ed., John Wiley \& Sons Inc, New York, pp 359417.
Griffing, B (1956) Concept of general and specific combining ability in relation to diallel crossing systems. Aust J Biol Sci 9, 463-493.

Haridy, MH; Abd El-Zaher, IN (2015) Heterosis and combining ability in bread wheat (Triticum aestivum, L.). Minia J Agric Res Develop 35, 59-67.

Kamaluddin, RM Singh; Prasad, LC; Abdin, MZ; Joshi, AK (2007) Combining ability analysis for grain filling duration and yield traits in spring wheat (Triticum aestivum L. em. Thell.) Genetics and Molecular Biology 30, 411-416.

Kutlu, I; Sirel, Z (2019) Using line $\times$ tester method and heterotic grouping to select high yielding genotypes of bread wheat (Triticum aestivum L.). Turk J Field Crops 24, 185-194.

Mosanaei, H; Ajamnorozi, H; Dadashi, MR; Faraji A (2017) Improvement effect of nitrogen fertilizer and plant density on wheat (Triticum aestivum, L.) seed deterioration and yield. Emir J Food Agric 29, 899-910.

Motawea, MH (2017) Estimates of heterosis, combining ability and correlation for yield and its components in bread wheat. J Plant Production 8, 729-737.

Nathan, NSH; Moubarak, MYGH (2016) Combining ability for yield and yield components in bread wheat under two nitrogen levels. Egypt J plant Breed 20, 363-372.

Saleh, SH; Amal Z Mohamed (2016) Performance and combining ability in diallel crosses of durum Wheat under two levels of nitrogen fertilization. Egypt J plant Breed 20, 953-968.

Shrief, SA; Abd El-Shafi, MA; El-Sadi, SA (2017) Heterosis, gene action and combining ability of grain yield and its components in six bread wheat crosses. Biosci Res 14, 12041215. 
مجلة اتحاد الجامعات العربية للعلوم الزراعية، جامعة عين شمس، القاهرة، مصر

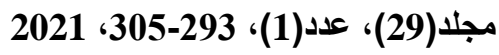

Website: http://ajs.journals.ekb.eg

DOI: 10.21608/ajs.2021.59713.1337

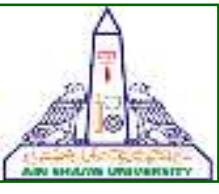

305

\section{القدرة علي الائتلاف لمحصول الحبوب وبعض الصفات المحصولية في هجن تبادلية من قمح الخبز تحت ظروف الاجهاد النيتروجينى}

[18]

ياسمين طارق محمد امام" - كمال امام محمد ابراهيم - احمد عبد الصادق محمد - ياسرعبد الجواد الجابرى قسم المحاصيل - كلية الزراعة - جامعة عين شمس - ص.ب 68 .حدائق شبرا 11241 - القاهرة - مصر

*Corresponding author: YassminTarek@agr.asu.edu.eg

Accepted 10 March, 2021

الصفات مما يوضح امكانية الانتخاب للصفات المرغوبة

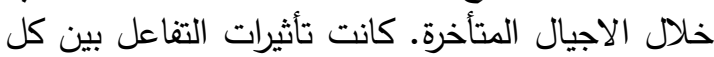
من القدرة العامة والخاصة علي الإنة الائتلاف والتسميد

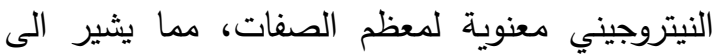

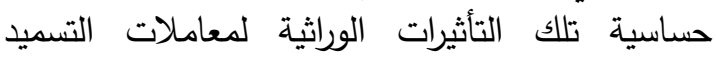

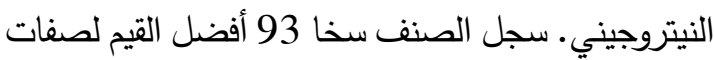

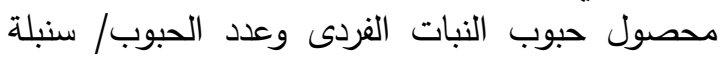
ووزن ال 100 حبة تحت ظروف الاجهاد النيتروجيني وكذلك لصفة ارتفاع النبات تحت مستويي التسميد، بينما

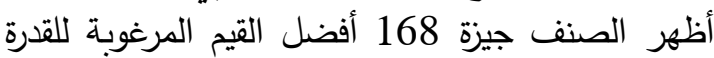
العامة على الائتلاف لصفة طول السنبلة تحت المستوى الصن

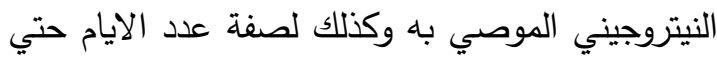
الطرد تحت مستويي التسميد النيتروجيني. و كان كان التيني

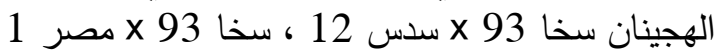

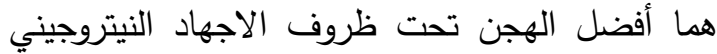

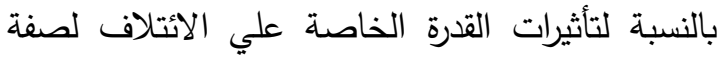

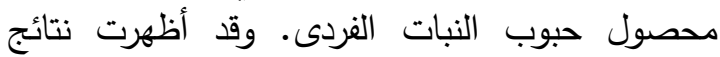
الارتباط امكانية استخدام متوسط السلوك للاباء والهجن كمؤشر على قدرتهما العامة والخاصة على على الائتلاف

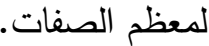

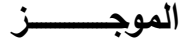

أجرى هذا البحث لتقييم 21 تركيب وراثى من القتح اشتملت على 6 أباء و15 هجين ناتج من دائرة تهجينات

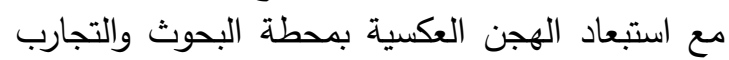
الزراعية لكلية زراعة عين شمس بشلقان - محافظة القليوبية. فى موسم 19/2018 تم تقييم الآباء والهجن الناتجة تحت مستويين من التسميد النيتروجينى هما 80 و40 كجم نيتروجين/ فدان. نفذت كل معاملة تسميد فى في التيد

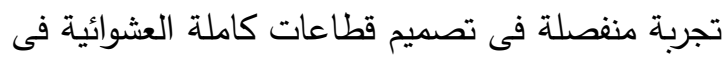
ثلاث مكررات لدراسة القدرة على التآلف لمحصول الحبوب والصفات المساهمة. وقد اظهرت الترات نتائج تحليل التباين وجود اختلافات معنوية بين التراكيب الوراثية وبين

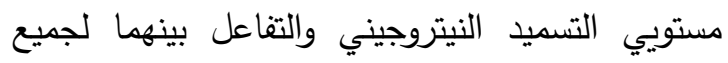
الصفات. وكان متوسط مجموع مربعات القدرة العامة

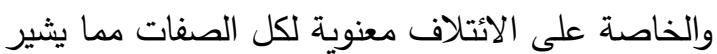

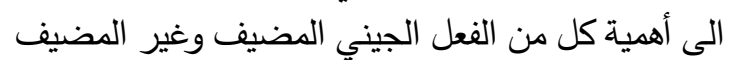

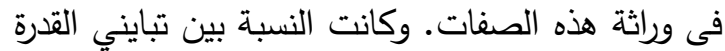

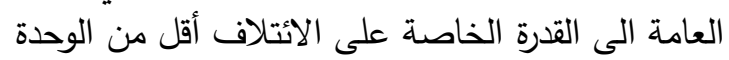

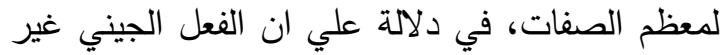
المضيف يمثل الجزء الاكبر من التباين الوراثى لجميع الفيل الجير 